\title{
The Fly-Ash Based Geopolymer Composites as an Innovative Material for Circular
}

\author{
Michat Łach ${ }^{l}$, Agnieszka Grela ${ }^{2}$, Barbara Kozub ${ }^{l}$, Kinga Korniejenko $^{\text {* }}$, \\ and Brian Azzopardi ${ }^{3}$ \\ ${ }^{1}$ Institute of Materials Engineering, Faculty of Material Engineering and Physics, Cracow University \\ of Technology, Jana Pawła II 37, 31-864 Cracow, Poland \\ ${ }^{2}$ Department of Engineering and Water Management, Faculty of Environmental and Power \\ Engineering, Cracow University of Technology, Warszawska 24, 31-155 Cracow, Poland \\ ${ }^{3}$ MCAST Energy Research Group, Malta College of Arts, Science and Technology, Triq Kordin, \\ Raћal Ġdid, 2001, Paola, Malta
}

\begin{abstract}
A circular economy is the answer to the problem of wasting raw materials and increasing environmental pollution. It is based on the effective use of materials - from extraction, through use, to the way of managing waste. Analyzing the impact of particular industries on the production of pollution, it can be concluded that the construction is one of such industries. In order to reduce the negative impact of the construction on the environment resulting from energy consumption and large amounts of generated waste, various researches are carried out on modern and innovative materials production solutions. One of the possibilities is a production technology based on the alkaline-activated compositions and geopolymers. The advantage of this technology is that it has a much lower carbon footprint compared to the traditional production methods used in construction - during the synthesis of geopolymers the emission of $\mathrm{CO} 2$ is 4-8 times lower and also the energy consumption is reduced up to 2-3 times. This article shows the possibility of using the industrial and mining waste for creating new eco-friendly materials - geopolymers. The paper presents the results of studies on geopolymer composites reinforced with addition of $1 \%$ by weight of different types of natural fibers i.e.: short hemp fibres, raw flax fibres (shortened), long flax fibres (stannous) and linseed cotonin. The paper showed that geopolymer composites can be successfully produced with the addition of natural fibres (often waste) and have good strength parameters even after long-term use.
\end{abstract}

\section{Introduction}

The circular economy, which has been gaining in importance over the last dozen or so years, is the opposite of the existing linear economy model based on the "take, produce, use and throw away" principle. The main objective of a circular economy is to preserve the value of resources within the economy. The transformation of waste into resources is a part

\footnotetext{
*Corresponding author: kinga.korniejenko@mech.pk.edu.pl
} 
of the process of closing the cycle in the circular management systems [1]. Analysing the impact of particular industries on the production of pollution, it can be concluded that construction is one of such industries [2,3]. In order to reduce the negative impact of construction on the environment resulting from energy consumption and large amounts of generated waste, various researches are carried out on modern and innovative material solutions [4, 5]. The Portland cement production technology, dating back to the 20th century, has a number of drawbacks, including: a very high energy consumption, consumption of a large amount of natural resources, environmental pollution (very high $\mathrm{CO}_{2}$ and highly toxic nitrogen oxides emission), and additionally the durability of the material is questioned. An alternative is a technology based on alkaline-activated compositions and geopolymers $[6,7]$. The advantage of this technology is also the fact that it has a much lower carbon footprint than the traditional building materials (during the synthesis of geopolymers the emission of $\mathrm{CO} 2$ is 4-8 times lower and also the energy consumption is reduced up to 2-3 times) [2]. Another advantage is that geopolymers are obtained using anthropogenic minerals (e.g. alternative aggregates produced from waste materials from the power and heating industry - slags and ashes) [1]. Anthropogenic minerals are an opportunity for the Polish economy to obtain a significant amount of raw materials for production throughout the country [8]. Taking into account the external conditions related to the conducted pro-climate policy, and the need to implement the principles of a waste free economy (Zero Waste Europe), resource efficiency (Resource Efficient Europe) and Circular Economy, it is necessary to focus on limiting the harmful effects of the energy generation process in Poland, by using the potential of this sector, so that the effects of its work constitute an added value for the economy and does not function as waste in our awareness [9].

Geopolymers are environmentally friendly materials and are structural materials with a significant chemical and thermal resistance. They have excellent mechanical properties, mainly compression and bending strength $[10,11]$. A relatively low resistance to brittle cracking is a limitation for the wide application of these materials [6]. However, it is already a research area that focuses on improving these mechanical properties [12, 13]. These properties are improved in the simplest way, i.e. by means of fibre reinforcement. From an ecological point of view (i.e. reduction of the so-called carbon footprint for a given product, reduction of $\mathrm{CO}_{2}$ emission, the use of natural fibres as a reinforcement material in geopolymer composites is beneficial [13]. Fibres have many beneficial features: reproducibility of raw material from annual plants which have a short vegetation cycle [14], low production costs, in comparison to chemical fibres [15, 16], low density [17], high specific strength [18], non-toxic to humans and harmless to the environment [19], easy to process and have low production cost" [13]. These features make them popular as reinforcements in various types of composites, including plastics and concrete [20].

\section{Geopolymer composites - raw materials}

Geopolymer composites reinforced with natural fibres are an excellent material that fits into the principles of circular economy. For their production, anthropogenic waste such as fly ashes and various types of natural (renewable) fibres are used. Scientists in their research and works describe several different types of raw materials from which geopolymer composites can be produced. When selecting the ash, it should be remembered that for the synthesis of geopolymers, F class ash is recommended, which contains less than $4 \%$ calcium oxide in its composition [21, 22, 23, 24, 25, 26]. The higher content of quicklime complicates the production process, due to required increase of process temperature [27]. Alomayri et al. used for the production of geopolymer F class fly ash from Collie power plant in Western Australia and reinforcement in the form of addition of 0.3, 0.5, 0.7 and 
$1.0 \%$ by weight of cotton fibres. The research showed that the addition of cotton fibres up to $0.5 \%$ by weight increases the compressive and bending strength, the modulus of elasticity and brittle fracture strength of the composites. However, a further increase in the addition of cotton fibres - above $0.5 \%$ by weight - caused a decrease in mechanical properties. The diagnosed cause was poor workability of the mixture, causing the formation of hollow spaces (poor dispersion of fibres in the matrix) and agglomeration of fibres [14, 28].

In turn, Amalia et al. used $\mathrm{C}$ class fly-ash and introduced reinforcement as an addition of $0.2,0.4,0.6,0.8$ and $1.2 \%$ of pineapple leaf fibres by weight. These fibres in geopolymers improve mechanical properties, i.e. compression and bending strength of the composites and do not change the resistance of geopolymers to high temperatures and acids [29]. The authors [37] used short hemp fibres (20-30 $\mathrm{mm}$ in size) in the amount of $4 \%, 6 \%$ and $8 \%$ of the weight of the composite and fly ash from PEGO CHP plant in Portugal. Significant decrease in mechanical properties was observed for $8 \%$ hemp fibre addition, decrease in compression strength after 28 days $45 \mathrm{MPa}$ obtained for matrix to $12 \mathrm{MPa}$ for samples with hemp fibre addition, and for bending strength - decrease from 3.4 MPa for pure matrix to 2.1 MPa. Coconut fibres were used by Amalia et al. [30]. To create geopolymer composites they used fly ash from Bosowa power plant in Jeneponto, South Sulawesi and coconut fibres from the plant trunk (fibre size $30-50 \mathrm{~mm}$; addition $0.25,0.5$, $0.75,1 \%$ by weight). An improvement in mechanical properties was obtained only for the composite containing $0.5 \%$ of fiber - 76.4 MPa flexural strength (compared with 74.4 MPa for the matrix material) and $89.4 \mathrm{MPa}$ compression strength (compared with $80.7 \mathrm{MPa}$ for the osmium material). An interesting research describing the use of natural material as a reinforcement in geopolymer composites is Chen et al. work [31], where an F class ash heap and an addition of sweet sorghum pomace in the amount of $1,2,3 \%$ by weight, (length of fibres: $10 \mathrm{~mm}$ ) were used. For such compositions, the compressive strength was slightly lower with the addition of the fibre, the tensile and bending strength, increased with sweet sorghum fibre content up to $2 \%$, and then decreased - a change in material behaviour during cracking from brittle (samples without fibres) to more ductile (for samples with fibres) was observed. The authors of the paper [32] used F class ash from the power plant of GK Kiel GmbH in Germany, with the addition of metakaolin and $10 \%$ by weight of fibres from the wood industry. For the created composites, they obtained a decrease in compressive strength but an improvement in bending strength.

Flax and hemp fibres are also very often used as reinforcing materials in geopolymer composites. Flax and hemp are two natural fibres which can be grown in Poland, so they are the most promising additives to geopolymer composites. These plants are classified as fibrous plants. The cellulose fibres of flax (Linum usitatissimum) are derived from the stem of this plant $[33,34]$ and have a number of interesting properties and applications. Hemp (Cannabis sativa) is one of the most commonly used cellulose fibres as reinforcement in various types of composites [33]. Their main advantages are the rapid growth of plants from which the fibres are obtained (only 3.5 months) and high production of dry biomass from the arable area $[35,36,37]$.

The studies on using flax as a reinforcement were carried out on various types of geopolymer matrices. The raw material for geopolymer production was for example: dehydroxylated kaolinite (kaolinite clay obtained from New Zealand halloysite - class Imerys Premium after baking at $600^{\circ} \mathrm{C}$ ) [34], low-calcium fly ash (ASTM F class, originating from Eraring power plant in New South Wales, Australia) [38], as well as fly ash with nanosilica added [39, 40,41]. Studies with hemp fibre reinforcements were carried out using foamed geopolymer matrices for which metakaolin was the base material. The foaming substance was a silicon metallic powder. Another geopolymer matrix, for which the short-fibre reinforcement was used, was a matrix based on: fly ash (coming from the 
PEGO thermal power plant in Portugal), glass waste and Portland cement as well as recycled aggregates [37].

\section{Methodology}

Fly ash from Skawina Combined Heat and Power Plant and Czech-made metakaolin were used as a waste source of aluminosilicates. Metakaolin should not be treated as a waste source, but tests were carried out using it to compare parameters obtained for elements from waste sources with natural materials of good quality. The oxide composition of precursors is shown in Table 1, based on XRF tests received from suppliers.

Table 1. Oxide composition of fly ash and metakaolin used in the tests.

\begin{tabular}{|c|c|c|c|c|c|c|c|c|}
\hline & \multicolumn{7}{|c|}{ Oxide composition (wt.\%) } \\
\cline { 2 - 10 } & $\mathrm{SiO}_{2}$ & $\mathrm{TiO}_{2}$ & $\mathrm{Fe}_{2} \mathrm{O}_{3}$ & $\mathrm{Al}_{2} \mathrm{O}_{3}$ & $\mathrm{CaO}$ & $\mathrm{MgO}$ & $\mathrm{K}_{2} \mathrm{O}$ & $\mathrm{Na}_{2} \mathrm{O}$ \\
\hline Fly ash & 55.90 & 1.09 & 5.92 & 23.49 & 2.72 & 2.61 & 3.55 & 0.59 \\
\hline Metakaolin & 53.01 & 0.74 & 1.34 & 41.54 & 0.27 & 0.38 & 0.71 & 0.82 \\
\hline
\end{tabular}

Geopolymers were made using $10 \mathrm{M}$ sodium hydroxide $\mathrm{NaOH}$ aqueous solution together with aqueous solution of sodium silicate (aqueous glass) (weight ratio 1:2). Construction sand was also included in the compositions of geopolymers (the amounts are given in Tables 2 and 3 for particular compositions). To prepare alkaline solutions, technical sodium hydroxide in the form of flakes and an aqueous solution of sodium silicate - sodium glass R-145 with a molar module of 2.5 and density of about $1.45 \mathrm{~g} / \mathrm{cm}^{3}$ were used. The added water was tap water, no distilled water was used. The alkaline solution was prepared in such a way that solid sodium hydroxide was flooded with aqueous solution of sodium silicate and water. The solution was thoroughly stirred and left until the concentrations equalized and a constant temperature was reached. The solid components, i.e. fly-ash or metakaolin, armouring fibres and sand, were mixed dry until a homogeneous mixture was obtained, then the alkaline solution was added and stirred thoroughly. Mixing was carried out in a laboratory mixer (LMB-s; standard mixer according to PN-EN 196) for about 15 minutes. After obtaining a homogeneous mass of densely plastic consistency, the mixture was transferred to the moulds, which were then vibrated on a vibrating table. Moulded geopolymer concretes were heated in a laboratory dryer for 24 hours at $75^{\circ} \mathrm{C}$ in the atmospheric pressure. After 24 hours, the samples were removed and disassembled.

Compressive strength tests of geopolymer samples were carried out 360 days after demoulding. Initially, samples were stored for 270 days at about $20^{\circ} \mathrm{C}$ and $60 \%$ humidity. After 270 days, the samples were used to build a test wall, which was tested for the next 90 days for the occurrence of efflorescence, cracks and other types of damage under changing weather conditions (in the temperature range $-5^{\circ} \mathrm{C} \div+20^{\circ} \mathrm{C}$ and various humidity). After

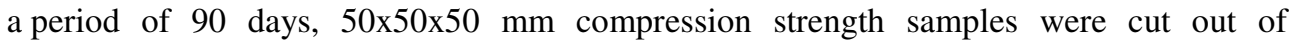
geopolymer elements and these tests were carried out. The compressive strength tests were carried out with the use of the Matest $3000 \mathrm{kN}$ testing machine.

The following materials were used as reinforcing fibres:

- short hemp fibres,

- raw flax fibres (shortened),

- long flax fibres (stannous),

- linseed cotonin.

The fibres were supplied by the Institute of Natural Fibres and Herbal Plants in Poznań. The research was carried out by producing geopolymer composites with multiple variants. 
Solid bricks based on metakaolin and fly ashes as well as plates with solid layer and foaminsulating layer were produced. All layers were reinforced by the addition of $1 \%$ of fibre weight. Hydrogen peroxide $\mathrm{H}_{2} \mathrm{O}_{2} 35 \%$ was used as a blowing agent in the production of foamed geopolymers. It was introduced in the last stage of mixing, each time in the amount of $2 \%$ by weight in relation to the weight of fly ash or metakaolin.

\section{Results}

Figure 1 illustrates the appearance of manufactured geopolymer composites reinforced with natural fibers. The photographs show composites in the form of bricks and plates with two layers: foamed and solid. In case of photographs of sandwich panels, clusters of fibres in foamed parts are visible. This is an effect of uneven mixing of fibres and their aspiration to agglomeration. This phenomenon occurred especially in the production of foamed composites.
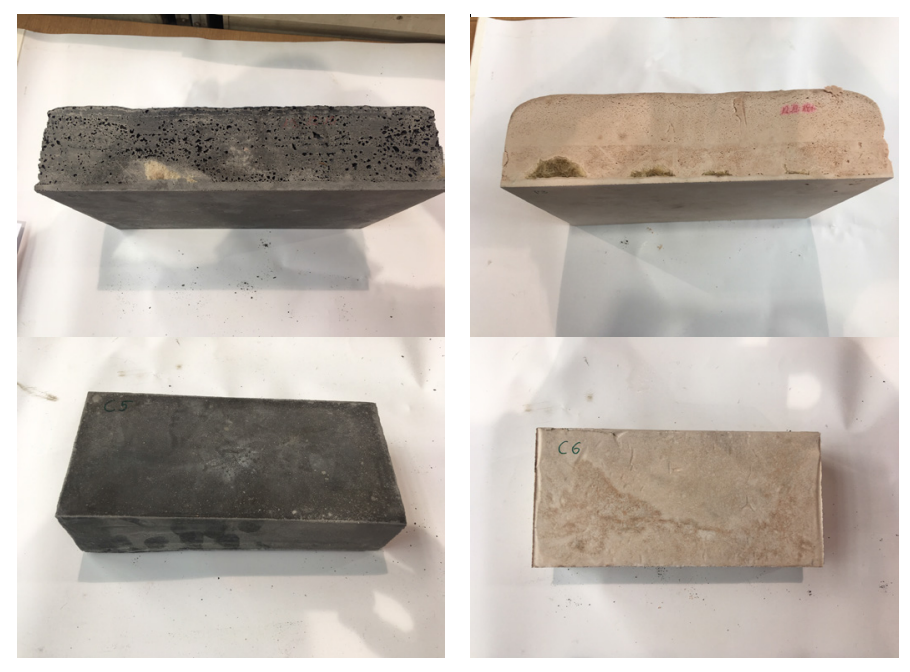

Fig. 1. Examples of geopolymer elements prepared for testing: a panel with a facade facing layer and insulation layer - foamed and solid brick.

The manufactured geopolymer composites with natural fibres, after being seasoned for 270 days, were used to build a small test wall. In the construction of the wall they were tested for another 90 days. Figures 2 and 3 show the constructed wall and samples which were cut and prepared for further strength tests.

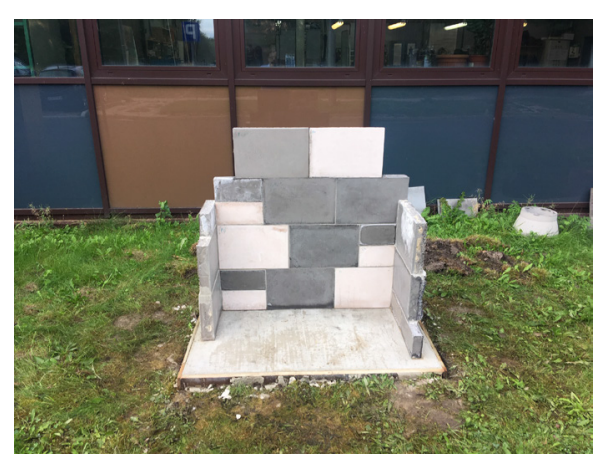

Fig. 2. A test wall made of geopolymer elements, tested for 90 days. 


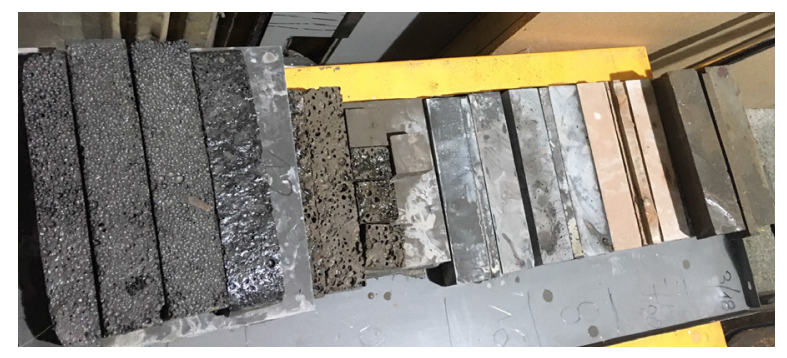

Fig. 3. Samples prepared for strength tests, cut out from the tested elements built into the tested geopolymer wall.

After 360 days of seasoning in various climatic conditions, fibre-reinforced geopolymer composites were subjected to bending strength and compressive strength tests. The results are presented below in Tables 2 and 3. The results obtained are a confirmation of the work of many authors so far, for example in paper [36] where for hemp fibres the reinforcement was directional in nature and was made using a hemp fibre net. The results obtained showed that hemp-grid reinforced composite can be used in construction applications because of the good connection between matrix and reinforcement, good dimensional stability under varying thermal conditions and good mechanical properties [36]. Studies on the addition of short flax fibres to geopolymer composites based on fly ash were also conducted at the Institute of Material Engineering of the Faculty of Mechanical Engineering of the Cracow University of Technology [41]. In particular studies, the addition of flax fibre in the amount of $1 \%$ was used. The results showed an improvement in mechanical properties through the addition of flax fibres, in particular bending strength.

The results presented in Table 2 show that the highest compressive strength values were obtained for the solid composite based on fly ash, reinforced with short hemp fibres. The value of the compressive strength was as high as $90.8 \mathrm{MPa}$. In relation to the geopolymers presented in the paper [42], it should be considered that this is a value that proves that these fibres reinforced the geopolymer matrix. High values above $75 \mathrm{MPa}$ were also obtained for composites based on raw (shortened) flax fibre reinforced ashes, as well as for flax cotonin. Geopolymers based on metakaolin were characterized by much lower compressive strength values compared to those based on fly ash. In case of geopolymer composite based on metakaolin, reinforced with raw, shortened flax fibers, the value of compression strength was only $42.8 \mathrm{MPa}$. It should be noted that in case of geopolymer composites based on metakaolin, higher values of flexural strength were observed in comparison with those based on fly ash. Geopolymers made of metakaolinium reinforced with flax cotonin and flax fibres were characterized by flexural strength above $10 \mathrm{MPa}$. For composites based on fly ash the highest value of compressive strength was that of composite reinforced with short hemp fibres.

Table 2. Results of compressive and flexural strength test of geopolymer elements in the form of fiber-reinforced bricks.

\begin{tabular}{|c|c|c|c|}
\hline $\begin{array}{c}\text { Composite matrix - } \\
\text { geopolymer }\end{array}$ & $\begin{array}{c}\text { Reinforcement - } \\
\text { fibre (1\% weight) }\end{array}$ & $\begin{array}{c}\text { Compressive Strength, } \\
\text { [MPa] }\end{array}$ & $\begin{array}{c}\text { Flexural strength, } \\
\text { [MPa] }\end{array}$ \\
\hline Sand+Fly ash, 1:1 & flax shortened raw & 75.40 & 8.19 \\
\hline Sand+Fly ash, 1:1 & short hemp & 90.80 & 9.36 \\
\hline Sand+Fly ash, 1:1 & flax cotina & 76.74 & 8.26 \\
\hline
\end{tabular}




\begin{tabular}{|c|c|c|c|}
\hline Sand+Fly ash, 1:1 & flax longstems & 66.71 & 8.26 \\
\hline Metakaolin+Fly ash, 1:1 & flax longstems & 67.55 & 10.61 \\
\hline Metakaolin+Fly ash, 1:1 & flax shortened raw & 42.85 & 7.15 \\
\hline Metakaolin+Fly ash, 1:1 & flax cotonin & 66.39 & 10.67 \\
\hline
\end{tabular}

Table 3. Results of the compressive and flexural strength test of geopolymer elements in the form of foamed plates reinforced with natural fibers.

\begin{tabular}{|c|c|c|c|}
\hline $\begin{array}{l}\text { Composition of the } \\
\text { solid layer }\end{array}$ & $\begin{array}{l}\text { Composition of the } \\
\text { foamed layer }\end{array}$ & $\begin{array}{c}\text { Compressive Strength, } \\
{[\mathrm{MPa}]}\end{array}$ & $\begin{array}{c}\text { Flexural strength, } \\
{[\mathrm{MPa}]}\end{array}$ \\
\hline $\begin{array}{l}\text { Sand+Fly ash. 1:1 } 1 \% \\
\text { short flax fibre }\end{array}$ & $\begin{array}{c}\text { Sand+Fly ash. 1:3; } \\
1 \% \text { flax cotonin. } \\
2 \% \mathrm{H}_{2} \mathrm{O}_{2}\end{array}$ & 6.60 & 0.28 \\
\hline $\begin{array}{l}\text { Sand+Fly ash. } 1: 11 \% \\
\text { short flax fibre }\end{array}$ & $\begin{array}{c}\text { Sand+Fly ash. 1:5; } \\
1 \% \text { flax cotonin. } \\
2 \% \mathrm{H}_{2} \mathrm{O}_{2}\end{array}$ & 4.27 & 0.65 \\
\hline $\begin{array}{l}\text { Sand+Fly ash. 1:1 1\% } \\
\text { soaked shortened flax } \\
\text { fibre }\end{array}$ & $\begin{array}{c}\text { Sand+Fly ash. 1:5; } \\
1 \% \text { soaked flax } \\
\text { shortened. } 2 \% \mathrm{H}_{2} \mathrm{O}_{2}\end{array}$ & 6.83 & 0.14 \\
\hline $\begin{array}{l}\text { Sand+Fly ash. } 1: 11 \% \\
1 \% \text { fibre long flax }\end{array}$ & $\begin{array}{c}\text { Sand+Fly ash. } 1: 5 ; \\
1 \% \text { flax cotonin. } \\
2 \% \mathrm{H}_{2} \mathrm{O}_{2}\end{array}$ & 12.65 & 2.50 \\
\hline $\begin{array}{l}\text { Sand+Fly ash. } 1: 1 ; 1 \% \\
\quad \text { flax short }\end{array}$ & $\begin{array}{c}\text { Sand+Fly ash. 1:5 } \\
1 \% \text { flax cotonin. } \\
2 \% \mathrm{H}_{2} \mathrm{O}_{2} \\
\end{array}$ & 5.84 & 1.61 \\
\hline $\begin{array}{l}\text { Sand+Fly ash. } 1: 1 ; 1 \% \\
\quad \text { flax short }\end{array}$ & $\begin{array}{c}\text { Sand+Fly ash. 1:5; } \\
1 \% \text { flax cotonin. } \\
2 \% \mathrm{H}_{2} \mathrm{O}_{2}\end{array}$ & 6.94 & 0.05 \\
\hline $\begin{array}{l}\text { Sand+Fly ash. } 1: 1 ; 1 \% \\
\text { flax soaked shortened }\end{array}$ & $\begin{array}{c}\text { Sand+Metakaolin. } \\
1: 5 ; 1 \% \text { flax } \\
\text { soaked shortened. } \\
2 \% \mathrm{H}_{2} \mathrm{O}_{2} \\
\end{array}$ & 6.76 & 0.86 \\
\hline
\end{tabular}

The results presented in Table 3 show the compressive and flexural strength values for geopolymer layered panels. which have been reinforced with various types of fibres. The fibres were used both for the insulation part. foamed and solid. which thickness did not exceed $1 \mathrm{~cm}$. The obtained values are in fact the resultant values of the whole layered composite. The highest compressive strength value of $12.65 \mathrm{MPa}$ was obtained for the composite with foamed layer with flax cotonin and solid layer with flax-stem fibers. This composite also had the highest flexural strength value of $2.5 \mathrm{MPa}$. All of the obtained layered composites had a compressive strength above $4 \mathrm{MPa}$. These values were small due to the low strength of the foamed layers. The high degree of foaming also resulted in a decrease in the bending strength values of the composites produced.

Natural fibres in this type of composites were used to improve the mechanical properties of geopolymer foams and also to improve bending strength for solid composites. In the case of non-foamed composites. it often happens that the addition of fibres. due to the reduction of the active cross-section of the sample. also reduces the value of the compressive strength. However. the flexural strength parameters are usually improved. 
Often. despite a significant decrease in mechanical properties. many authors emphasize the advantages of new composites. including the environmental benefits. i.e. a reduction in the carbon footprint. associated with the use of natural fibres [37].

\section{Summary}

The paper presents the results of studies of geopolymer composites reinforced with addition of $1 \%$ weight of different types of natural fibers. Composites based on metakaolin and fly ash were prepared. The studies showed that geopolymer composites reinforced with natural fibers are characterized by good mechanical properties. For the solid composite based on fly ash. reinforced with short hemp fibers. the compressive strength value was as high as 90.8 MPa. High values above $75 \mathrm{MPa}$ were also obtained for composites based on raw (shortened) flax fibre reinforced ashes as well as for flax cotonin. For geopolymer layer panels. reinforced with various types of fibres. which were used both for the insulation part. foamed and solid (thickness not exceeding $1 \mathrm{~cm}$ ). the highest compressive strength value of 12.65 MPa was obtained for a composite with foamed layer with flax cotonin and solid layer with flaxenenene-stemmed fibres. This composite also had the highest flexural strength value of $2.5 \mathrm{MPa}$. All the obtained layered composites had a compressive strength above $4 \mathrm{MPa}$.

The paper showed that geopolymer composites can be successfully produced with the addition of natural fibres (often waste) and have good strength parameters even after longterm use (materials were tested after 360 days). It is worth noting that the geopolymer composites discussed in this paper were exposed to large apmlitude of temperatures and humidity. and yet they showed no signs of degradation or decrease in their initial strength.

\section{Acknowledgements}

This work has been financed by Polish National Agency for Academic Exchange under the International Academic Partnership Programme within the framework of the grant: Emobility and sustainable materials and technologies EMMAT (PPI/APM/2018/1/00027). This work also has been supported by the National Centre for Research and Development in Poland under the grant: Low thermal conductivity geopolymer foams produced with industrial wastes as an innovative material for circular economy (LIDER/31/0168/L10/18/NCBR/2019). This work also has been supported by the ERANet-LAC 2nd Joint Call (www.eranet-lac.eu) funded by the National Centre for Research and Development inPoland. within the framework of the grant: 'Development of eco-friendly composite materials based on geopolymer matrix and reinforced with waste fibers

\section{References}

1. D. Szczygielska, Mineraty antropogeniczne a gospodarka o obiegu zamkniętym (Politechnika Warszawska, Warszawa, 2015) (in Polish)

2. J. Mikuła, M. Łach, Rozwiazania proekologiczne w zakresie produkcji. Nowoczesne materiaty kompozytowe przyjazne środowisku (Wydawnictwo Politechniki Krakowskiej, Kraków, 2014) (in Polish)

3. I. Z. Bribián, A. V. Capilla, A. A. Usón, Build. Environ. 46, 5 (2011)

4. J. Mikuła, K. Korniejenko, Diagnosis and material issues in the 20th century architecture (Wydawnictwo Politechniki Krakowskiej, Kraków, 2016) 
5. I. Hager, Energy efficient, sustainable building materials and products (Wydawnictwo Politechniki Krakowskiej, Kraków, 2017)

6. K. Korniejenko, E. Frączek, E. Pytlak, M. Adamski, Procedia Eng. 151 (2016)

7. A. Palomo, P. Krivenko, I. Garcia-Lodeiro, E. Kavalerova, O. Maltseva, A. FernándezJiménez, Materials de Construccion. 64 (2014)

8. M. Łącka-Matusiewicz, K. Fraś, Popioty $z$ energetyki. XI Międzynarodowa Konferencja (Polska Unia Ubocznych Produktów Spalania, Sopot, 2012) (in Polish)

9. T. Szczygielski, Popioty z energetyki. XXI Międzynarodowa Konferencja (Polska Unia Ubocznych Produktów Spalania, Zakopane, 2014) (in Polish)

10. J. Davidovits. Geopolymer Chemistry and Applications (Geopolymer Institute, SaintQuentin, 2015)

11. S. L. Lyu, T. T. Wang, T. W. Cheng, T. H. Ueng, Constr. Build. Mater. 43 (2013)

12. A. Bentur, S. Mindess, Fibre reinforced cementitious composites (Taylor and Francis, London and New York, 2007)

13. J. Mikuła, K. Korniejenko, Innovative. Cost-Effective and Eco-friendly Fibre-based Materials for the Construction Industry (Wydawnictwo Politechniki Krakowskiej. Kraków. 2015)

14. T. Alomayri, F. U. A. Shaikh, I. M. Low, J. Mater. Sc. 48 (2013)

15. L. Kidalova, N. Stevulova, E. Terpakova, A. Sicakova, J. Clean. Prod. 34 (2012)

16. T. Alomayri, F. U. A. Shaikh, I. M. Low, Compos. Part B. 50 (2013)

17. N. Ganesan, R. Abraham, S. Deepa Raj, Constr. Build. Mater. 93 (2015)

18. H. Rashidian-Dezfouli, P. R. Rangaraju, Constr. Build. Mater. 153 (2017)

19. F. Pacheco-Torgal, S. Jalali, Constr. Build. Mater. 25, 2 (2011)

20. E. A. Correia, S. M. Torres, M. E. O. Alexandre, K. C. Gomes, N. P. Barbosa, S. D. E. Barros, Mater. Sci. Forum. 758 (2013)

21. D. Hardjito, B. V. Rangan, Development and Properties of Low-Calcium Fly Ashbased Geopolymer Concrete. Research Report GC-1 (Curtin University of Technology, Perth, 2005)

22. S. E. Wallah, B. V. Rangan, Low-Calcium Fly Ash-Based Geopolymer Concrete: Long-Term Properties. Research Report GC2 (Curtin University of Technology, Perth, 2006)

23. T. W. Cheng, J. P. Chiu, Min. Eng. 3 (2003)

24. M. D. J. Sumajouw, B. V. Rangan, Low-calcium fly ash-based geopolymer concrete: reinforced beams and columns. Research Report GC 3 (Curtin University of Technology, Perth, 2006)

25. U. Rattanasak, P. Chindaprasirt, Min. Eng. 22, 12 (2009)

26. A. S. De Vargas, D. C. C. Dal Molin, A. C. F. Vilela, F. J. De Silva, B. Pavao, H. Veit, Cem. Concr. Compos. 3, 6 (2011)

27. J. L. Provis, J. S. van Deventer, Geopolymers. Structure, processing, properties and industrial applications (CRC Press. 2009)

28. T. Alomayri, F. U. A. Shaikh, I. M. Low, Mater. Des. 57 (2014)

29. N. Amalia, S. Hidayatullah, A. I. I. Nurfadilla, J. Subaer, Mater. Sc. Eng. 180 (2017)

30. N. Amalia, N. Akifah, A. I. I. Nurfadilla, J. Subaer, Conf. Ser.: Mater. Sci. Eng. 180 (2017) 
31. R. Chen, S. Ahmari, L. Zhang, J. Mater. Sc. 49 (2014)

32. P. Duan, C. Yan, W. Zhou, W. Luo, Constr. Build. Mater. 111 (2016)

33. L.Yan, B. Kasal, L. Huang, Compos. Part B. 92 (2016)

34. H. Assaedi, T. Alomayri, F. U. A. Shaikh, I. Low, Adv. Mater. Res. 3, 3 (2014)

35. B. Galzerano, A. Formisano, M. Durante, F. Iucolano, D. Caputo, B. Liguori, J. Compos. Mater. 22 (2017)

36. L. Zampori, G. Dotelli, V. Vernelli, Env. Sc. Tech. 47, 13 (2013)

37. M. Mastali, Z. Abdollahnejad, F. Pacheco-Torgal, Constr Build Mater. 160 (2018)

38. H. Assaedi, T. Alomayri, F. U. A. Shaikh, I. Low, J. Adv. Ceram. 4, 4 (2015)

39. H. Assaedi, F. U. A. Shaikh, I. Low, J. Asian Ceram. Soc. 5 (2017)

40. H. Assaedi, F. U. A. Shaikh, I. Low, Compos. Part B. 95 (2016)

41. K. Korniejenko, M. Łach, J. Mikuła, G. Silva, R. Aguilar, S. Kim, J. Nakamatsu, New, eco-friendly materials based on geopolymer matrix for applications in construction industry. Conference Proceedings (Wydawnictwo Instytutu Inżynierii Materiałowej WM PK, Kraków. 2017)

42. M. Łach, K. Korniejenko, J. Walter, A. Stefańska, J. Mikuła, Materials 13 (2020) 